\title{
Leon Battista Alberti as Author of Hypnerotomachia Poliphili
}

\author{
Lionel March ${ }^{1}$
}

Published online: 20 August 2015

(C) Kim Williams Books, Turin 2015

\begin{abstract}
The enigmatic Hypnerotomachia Poliphili published anonymously in 1499 has long posed puzzles for historians and other scholars. This present text argues that the volume can credibly be attributed, not to Francesca Colonna as is often done, but to the Renaissance humanist and polymath Leon Battista Alberti. Evidence for this is found in the unravelling of arithmogrammatical evidence sprinkled throughout the work, similar to those found in other of Alberti's works.
\end{abstract}

Keywords Leon Battista Alberti - Hypnerotomachia Poliphili $\cdot$ Number symbolism · Gematria · Geometry · Ratios

The hybrid word hypnerotomachia may be understood to mean 'the strife of love in a dream.' The full translation of the book title is The Hypnerotomachia of Poliphilo, in which it is shown that all human things are but a dream, and many other things worthy of knowledge and memory (Jocelyn Godwin 1999). No author is named. The printer was Aldus Manutius (1450?-1515) (Fig. 1).

In the past few years, attention has been drawn to the book in the English language. The complete translation by Jocelyn Godwin (1999) is the first in the English language in 500 years. Helen Barolini (1992) provides a brief account of Aldus Manutius's life and a summary glimpse of Hypnerotomachia. Alberto PérezGómez (1993) alerted the architectural community to the book's relevance for contemporary developments. All three of these authors seem comfortable with attribution to the monk Francesco Colonna of Venice as author. Liane Lefaivre (1997) argues that the identity of the author is almost certainly the polymath, Leon

Lionel March

lmarch@g.ucla.edu

1 Spring Studio, 20 High Street, Stretham, Isle of Ely, UK 


\section{HYPNEROTOMACHIA POLIPHILI,VBI HV \\ MANA OMNIA NON NISISOMNIVM \\ ESSEDOCET.ATQVE OBITER \\ PLVRIMA SCITV SANE \\ QVAMDIGNA COM \\ MEMORAT. \\ *** * \\ ** \\ * \\ CAVTVMEST,NE QVISIN DOMINIO \\ ILL.S.V.IMPVNE HVNCLI \\ BRVMQVEAT \\ IMPPRIME \\ RE.}

Fig. 1 The title page inscription printed at the house of Aldus Manutius, Venice, December 1499

Battista Alberti (1404-1472). Robert Tavernor includes a brief discussion of the book in his monograph on Alberti (Tavernor 1998: pp. 28-29), in which he does not rule out the possibility of his subject's authorship, although he questions whether Alberti might have sketched the designs for the many woodcuts since some lack the decorum of istoria.

Ingrid Rowland (1998: pp. 59-67) points to the humanist readership of the novel upon its publication-necessarily diligent, intelligent and wealthy enough to afford such an expensively produced volume. Her example is Angelo Colocci, antiquarian, philologist, and eventual secretary to Leo X and Clement VII. In Rowland's opinion (1998: pp. 65), blatant errors in architectural descriptions rule Alberti out as author, an aspect upon which Jocelyn Godwin (1999: p. xi) also remarks. On the question of authorship, Rowland writes: 'The identity of the novel's putative author, "Francisco Colonna", is disputed today; both a Venetian monk and a Roman prince of that name have been proposed, but the name may be a pseudonym' (Rowland 1998: p. 60).

Several statements proceed the novel itself. Leonardo Crasso writes: "There has recently come into my hands a somewhat novel and admirable work of Poliphilo... which, in order that it shall not remain in darkness,... I have had printed and published at my own expense (quoted in Jocelyn Godwin 1999: p. 2).

Presumably a manuscript came into Crasso's hands sometime before 1499. The date given at the end of the novel is "The Kalends of May, 1467", or May Day, when the Romans celebrated the goddess Flora and, even today, sweethearts auspiciously declare their love. The provenance of the lost manuscript is unknown. Alberti died in 1472. If he was the author, the manuscript may have passed from his estate with other manuscripts without the identity of the author being recognized. A mildly erotic manuscript, it could then have gone from one reader to another, as such materials were wont to do, before arriving at Crasso's door.

Written in a polyglot language, the author combines Tuscan, or the vernacular, and Latin into new words and sentence structures with a sprinkling of Arabic, Greek 
and Hebrew in the illustrations. It has rightly been described by Lefaivre as protoJoycean literature, with many neologisms as in Alberti's Intercenales, or Dinner Pieces (Alberti 1987). Crasso writes: '[the author] arranged it such that none but the most learned should be able to penetrate the inner sanctum of his teaching; yet he who approaches it with less learning should not despair'.

Alberti commented on Vitruvius in these terms:

What he handed down was in any case not refined, and his speech such that the Latins might think that he wanted to be a Greek, while the Greeks would think that he babbled Latin. However, his very text is neither Latin nor Greek, so that as far as we are concerned he might as well not have written at all, rather than write something that we cannot understand (Alberti 1988: p. 154).

Jean Martin, the French translator of Vitruvius in 1547, quoting this passage from De re aedificatoria, comments: 'In my opinion, [Vitruvius] did this deliberately so as not to be understood by his ignorant contemporaries (quoted in Borsi 1975: p. 346).

This may be the case in Hypnerotomachia with this difference: if the author was Alberti, he was recognized as one of the very best Latinists of his time, and was the author of the first Tuscan grammar. His polyglot language was corrupted neither by time nor by lack of refinement. On the contrary, and in particular, the many neologisms, fusing Tuscan and Latin, are deliberate and extraordinarily inventive. The result is not "something that we cannot understand", but is beyond the understanding of "ignorant contemporaries," and the narrow-minded.

This comment makes the book a candidate for that category which Leo Strauss describes in his penetrating essay 'Persecution and the Art of Writing' (1988). But what persecution? Alberti, for example, had worked for Sigismondo Malatesta on the cloaking of Rimini's medieval church of St. Francis in antique Roman garb. At the time Alberti was an abbreviator in the papal court of Pius II (pp. 1458-1464). On Christmas Day 1460, Malatesta was excommunicated: and by April 1462, he was uniquely canonized to hell. The wrath of the Pope focussed on accusations of gross sexual misconduct and murder, but Malatesta's evident appetite for Platonic classicism and paganism must have played some part too. Writes Borsi: 'With Sigismondo [Alberti's] relations were fairly direct and open, to the extent that he came near to being considered ideologically suspect during Pius II's violent campaign against the lord of Rimini' (1975: p. 193).

On the death of Pius II, the papacy was assumed by Paul II, who began his pontificate by dismissing a number of humanists appointed by his predecessors. In 1464, he sacked the college of abbreviators, including Alberti who had by then been a member for 32 years. Suspicious that the humanists were plotting against him, Paul II next dissolved the Roman Academy, seized many of its members-though not Alberti-and accused them of treason. Several were tortured and died without any conspiracy against the Pope being proved. Failing this theory, Paul II then accused the prisoners of heresy for cultivating pagan rituals and ideas, but the inquisitors found no foundation for heretical conduct. Nevertheless, Paul II continued to keep some humanist locked up. 
Alberti would have been keenly aware of being tarred with the same brush as his persecuted colleagues. It would have been unwise for him to attract further investigation, and yet he might well have had an urge to defend aspects of the classical-yes, pagan-Roman world which he loved and respected. An anonymous novel, privately circulated, cast in the form of a dream provided a relatively riskfree vehicle for protesting the clamping down on humanistic endeavors and achievements. A dream sequence cannot be challenged ideologically for its contents in the public realm, but reading between the lines, initiates may glean its intended purport. Paul II himself would have been unlikely to be able to make sense of a manuscript in which the vernacular is so heavily Latinized. He was no intellectual; he never mastered Latin, and his support for the arts did not extend to literature.

The art of writing under persecution requires a shallow reading of the text by conservative persecutors, usually forced by the intrinsic difficulties of the language for which natural indolence has no time, and a deeper reading by radical followers who know the code and appreciate the hidden messages. Thus the Hypnerotomachia. It would make even more sense if the illustrations were drawn in the original manuscript - a matter of dispute - since the dreamwork could be read as a modestly erotic graphic novel without reference at all to the esoteric text. The persecutors could laugh the whole manuscript off as lightweight and unimportant, having never read a word of it.

Unless-unless - the author revealed his true identity. If Alberti, or any other notable humanist, had signed the dreamwork, the persecutors would have had to have taken it seriously.

The earliest recorded attribution of authorship is a note written in a copy of Hypnerotomachia in 1512 (Jocelyn Godwin 1999: p. xiv). The acrostic formed by the decorated initial letters (Fig. 2) of the thirty-eight chapters reads:

\section{POLIAM FRATER FRANCISCVS COLVMNA PERAMAVIT.}

(Brother Francisco Colonna greatly loved Polia)

It is difficult to imagine that the annotator in 1512 was the first to unravel this message. It is far from being a secure encryption. In any case why should this be read as a clue concerning authorship, and not patronage?

Suppose Alberti was the author. Francesco Colonna, fellow frater of the Roman Academy and known familially to Alberti (Lefaivre 1997: pp. 100-109), might possibly have been instrumental, knowingly or not, as child and pupil, in encouraging the telling of the original stories. Surely the acrostic makes as much sense as a privacy preserving dedication as it does as an acrostic identifying an author. Prince Colonna would have been 14 when the book was completed and 19 at Alberti's death. If it is dedicated to Francesco, it suggests that it is an episodic work told to a child over time from early days when the young Prince was Alberti's pupil. Pedagogical methods would explain architectural errors in some descriptions: find the mistakes! How alert is the reader?

Alberti was the author of "the first modern work of cryptography, De compendis cifris" (Williams et al. 2010: pp. 169-200) and has been named "the Father of Western Cryptography" (Kahn 1996: pp. 125-130). Continuing to assume that 

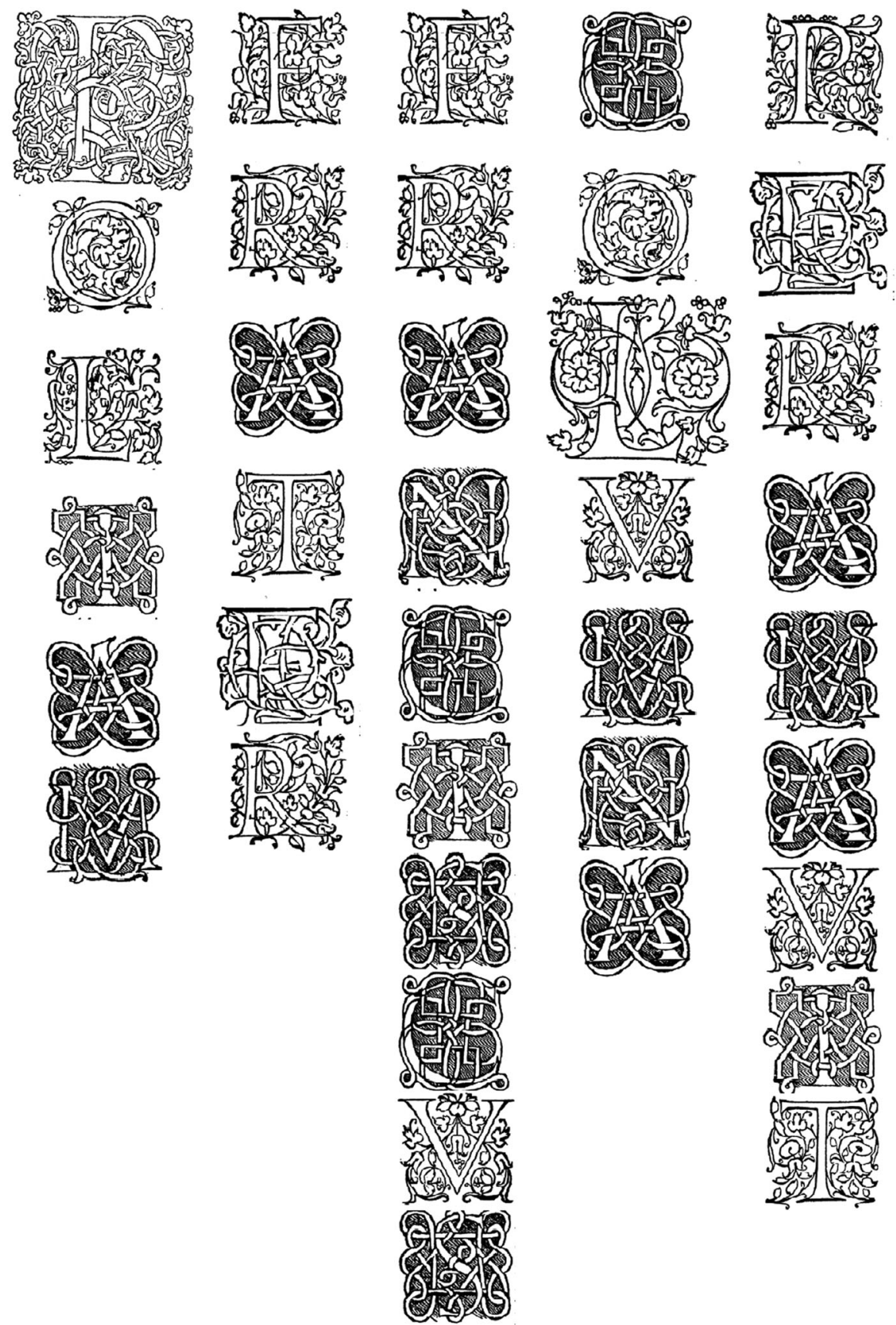

Fig. 2 The decorated initial letters from the 38 chapters of Hypnerotomachia arranged to reveal the acrostic 
Alberti is the author of Hypnerotomachia, it would not then be surprising to find that the text contains ciphers. Alberti wrote his tract on coding in 1466, or early 1467 , the year that the manuscript of Hypnerotomachia was completed. It is unlikely that Alberti would have used his own invention, the cipher disk, since its use requires that the two correspondents both have an identical disk. This makes sense in secret communications, but would seem an inappropriate method in a manuscript which might eventually be printed. Writing at the beginning of De compendis cifris, Alberti refers to the invention of moveable type and the greatly increased opportunity to reproduce a text for wide distribution (Williams et al. 2010: p. 171). The future reproduction of his novel's manuscript could not have escaped his attention at this time.

How to conceal his authorship and yet to leave an unmistakable signature on the work? That seems to have been the challenge under threat of persecution. At hand would have been the nine-chamber encoding derived from Hebrew gematria and the Greek pythmen of the Pythagorean calculus (Heath 1981: pp. 115-117) (Fig. 3). In both sources, a number may be read as a word, or a word as a number, since the characters have a dual meaning as letter and numeral. By analogy, a Latin version of the nine chambers was surely common knowledge and familiar to Alberti.

Born Battista Alberti, Alberti added Leon (Latin LEO) to his birth name around 1450 (Alberti 1988: p. xvi). Elsewhere (March 1999: p. 194) I have given numerical equivalencies for Alberti's Latin name. As inscribed on the medallion of Alberti by Matteo de' Pasti, the full name is spelled LEO BAPTISTA ALBERTVS. As with gematria, there are two simple ways of computing the numerical equivalence of a letter. The direct way is to use the numbers as assigned in the nine chambers. The Latin alphabet has 23 characters. There is no $\mathrm{J}, \mathrm{U}$ or W. Each letter is assigned a numerical value in 1-9 units, tens or hundreds. The 'small' way is to assign just the unit values. Thus, A, K, T are each assigned the unit value 1 ; the letters, B, L, V, the value 2, and so on. Both methods are used in Fig. 4.

Alberti's Latin name is thus associated with both the sum $12+30+30=72$ and the sum $75+363+498=936$.

There is one decorated letter which has been ignored in counting the acrostic. This is the letter $\mathrm{M}$ on the very first page of the text which heads the dedication to the fictitious Polia and thus precedes the acrostic itself (Fig. 5).

The value of this letter is 30, the number of both BAPTISTA and ALBERTVS in the small number nine chamber computation above. An examination of Alberti's

Fig. 3 The nine chamber encoding of the 23-letter Latin alphabet

\begin{tabular}{|l|l|l|}
\hline $\begin{array}{l}A=1 \\
K=10 \\
T=100\end{array}$ & $\begin{array}{l}\mathrm{L}=2 \\
\mathrm{~V}=20\end{array}$ & $\begin{array}{l}\mathrm{C}=3 \\
\mathrm{M}=30 \\
\mathrm{X}=300\end{array}$ \\
\hline $\begin{array}{l}\mathrm{D}=4 \\
\mathrm{~N}=40 \\
\mathrm{Y}=400\end{array}$ & $\begin{array}{l}\mathrm{E}=5 \\
\mathrm{O}=50\end{array}$ & $\mathrm{~F}=50$ \\
$\mathrm{P}=60$ & \\
\hline $\begin{array}{l}\mathrm{G}=7 \\
\mathrm{Q}=70\end{array}$ & $\mathrm{H}=8$ & $\mathrm{I}=9$ \\
& $\mathrm{R}=80$ & $\mathrm{~S}=90$ \\
\hline
\end{tabular}




$\begin{array}{rrrrrrrrr}\mathrm{L} & 20 & 2 & \mathrm{~B} & 2 & 2 & \mathrm{~A} & 1 & 1 \\ \mathrm{E} & 5 & 5 & \mathrm{~A} & 1 & 1 & \mathrm{~L} & 20 & 2 \\ \mathrm{O} & 50 & 5 & \mathrm{P} & 60 & 6 & \mathrm{~B} & 2 & 2 \\ & & & \mathrm{~T} & 100 & 1 & \mathrm{E} & 5 & 5 \\ & & & \mathrm{I} & 9 & 9 & \mathrm{R} & 80 & 8 \\ & & & \mathrm{~S} & 90 & 9 & \mathrm{~T} & 100 & 1 \\ & & \mathrm{~T} & 100 & 1 & \mathrm{~V} & 200 & 2 \\ & & \mathrm{~A} & 1 & 1 & \mathrm{~S} & 90 & 9\end{array}$

$\begin{array}{llllll}75 & 12 & 363 & 30 & 498 & 30\end{array}$

Fig. 4 Application of the nine chamber encoding to Alberti's Latin name

Fig. 5 The initial letter M

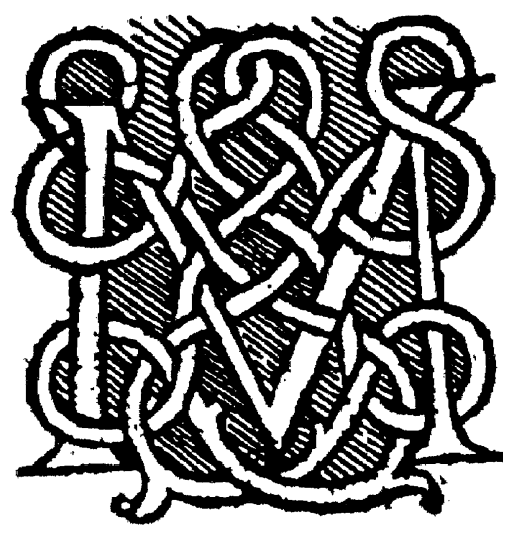

architecture shows that this is most likely to have been his characteristic signature (March 1999: pp. 182-205). In the Capella Rucellai, Alberti places 30 inlaid marble roundels around the tomb, 3 at the entrance and 9 each on the remaining three sides. Each of his three names reduce to the numerical value 3 in 'small' numbers: 12 is which reduces to $1+2=3$, and the $30 \mathrm{~s}$ which also reduce to 3 . In other words, a triple trinity.

The façade of Alberti's Santa Maria Novella, Florence, features two large volutes containing circular motifs. Each has an outer circle of 26 repeated elements with a wheel of 30 elements inside. This ratio 30:26 is very evident in the façade of Santa Maria Novella (March 1999: pp. 193-194). The façade was under construction from 1458 to 1470 when the work was dedicated, despite being unfinished. According to the imprint in the 1499 edition, the manuscript of Hypnerotomachia was completed in 1467.

The number 26 is associated with God as a gematriot for the Hebrew tetragrammaton, $\pi$ \% (March 1998: pp. 46-48; Scholem 1974: pp. 337-343), and with the 26 semi-axes of the cube. Surely, it is no accident that St Bonaventure's bible was divided into 5, 6, 5, 10 books (Bonaventure 1963) (Fig. 6). 


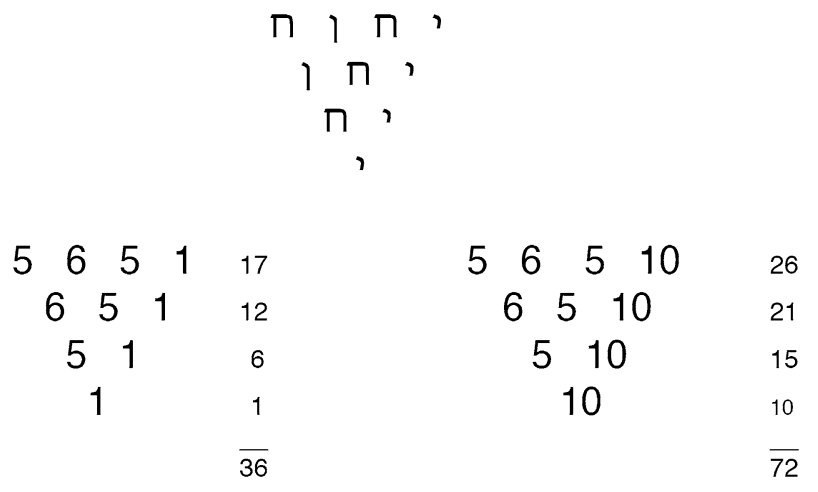

Fig. 6 Tetragrammatons showing the principal numerical interpretations in gematria
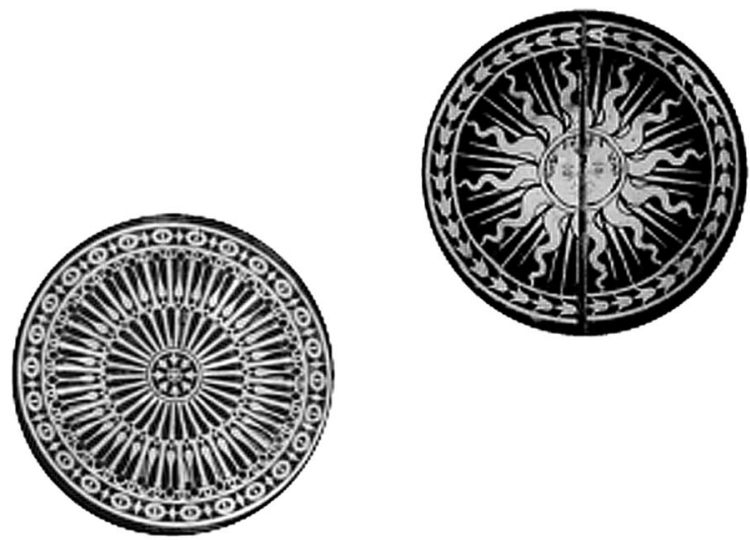

Fig. 7 The circular designs on the façade of Santa Maria Novella, Florence

These arrangements, both in the small number and the large number versions, appear to be mnemonics for common rational approximations to square roots, $\sqrt{ } 2$ and $\sqrt{ } 3$, such as might be used by masons: $21 / 15=7 / 5,17 / 12$ for $\sqrt{ } 2 ; 26 / 15$ for $\sqrt{ } 3 ; 26 / 21$ for $\sqrt{ } 3 / \sqrt{ } 2$.

Alberti had identified the unit cube with the Godhead in De re aedificatoria in 1450 (Alberti 1988: p. 307), and a similar reference is to be found in Hypnerotomachia: '[The cube] is consecrated to the Divinity, because it is produced from unity, and measures one on every side' (Jocelyn Godwin 1999: p. 130).

The two circles suggest that God, 26, both embraces and blesses the architect, Alberti, 30. At the crown of Santa Maria Novella is a sunburst with 12 radiating flames inscribed within a circle of 36 florets-another Divine number (Fig. 7). Reading from the top, and left to right, these inscribed decorative motifs spell the numbers $30+12+30=72$, Alberti's full name and, again, of Divine significance (Williams et al. 2010: pp. 189-199). Is this why Alberti added LEO, 12, to his birth 
name, $30+30=60$ ? Nor can it be accidental that the sun is identified with Leo in the zodiac. The sun is also the radiant motif that dominates Alberti's Cappella Sigismondo at Rimini, while Cappella dei Pianetti is decorated with the twelve signs of the zodiac (Borsi 1975: pp. 132-134). The ratio of inner ring to outer ring in the two volutes is $30: 26:: 15: 13$. This is a rational convergent to $\sqrt{4}: \sqrt{3}$. But note that the 48 radii under the radiating flames are circumscribed by 36 elements-a ratio of 4:3. The two ratios are related as in a family.

In Hypnerotomachia Poliphili, the dedication to Polia is spelled out POLIPHILVSPOLIAE, Poliphilo to Polia (in the dative case):

$$
\begin{gathered}
\text { POLIPHILVS }=6+5+2+9+6+8+9+2+2+9=58, \\
\operatorname{POLIA}(\mathrm{E})=6+5+2+9+1=23(+5=28) .
\end{gathered}
$$

These Latin names are fabrications of the author, but the numbers are familiar in Alberti's architecture. The ratio 29:23 has been shown to be implicit in Antonio Labacco's contemporary sketch of the plan of Alberti's San Sebastiano, Mantua (March 1998: p. 202). But the ratio of the two names is 58:23, or 2·29:23. A solution to the Delic problem of doubling the cube, in fifteenth century pre-decimal days, is given by a rational convergent to the cube root of 2 such as 29:23. For example, $29^{3}=24389,2 \cdot 23^{3}=24334$, an overestimate by less than $2 \%$.

Thus, the ratio 58:23 represents, in respect of side lengths, not a doubling of the cube but a 16 -fold volumetric multiplication. This ratio, equivalent to $2^{4 / 3}: 1$, has been shown to have been employed by Alberti in the elevations of Tempio Malatesta, Rimini (March 1999). While this may seem arbitrary, the ancient Roman system measured dry capacity in units, or as, of sextarii (Fig. 8)

The next largest measure was a modius, or 16 sextarii. The ratio 58:23, therefore, quite accurately provides the linear dimensional ratio between a cube of one

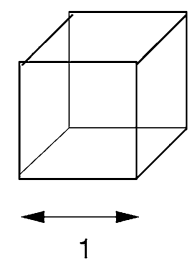

sextarius

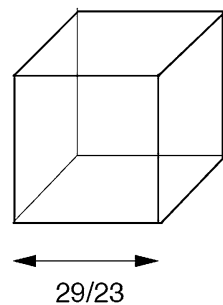

2 sextarii

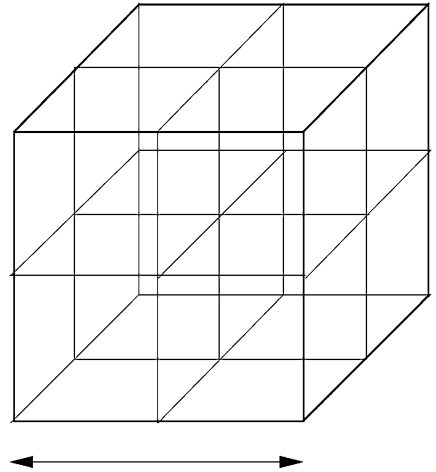

$58 / 23$

16 sextarii

modius

Fig. 8 Roman measures of dry capacity. Left, a unit of volume, sextarius, with a relative side of unit length, 1 ; center, a cube of twice the unit volume with a relative side length of 29/23; right, a cube of 16 sextarii, a modius, with a relative side length of $58 / 23$ 
sextarius and a cube of one modius. It is not simply that the cube of POLIA is doubled, but that it is multiplied 16-fold to produce the cube of POLIPHILVS. Since the sextarius is the unit, as, of Roman solid volumetric measures, a cube of this volume answers to Alberti's 'primary cube... consecrated to the Godhead, because the cube of one remains one' (Alberti 1988: p. 307).

POLIA, in this analogy, is identified with the divine. Poliphilo's desire is directed to Polia, POLIAE, and the dative case exhibits the perfection of the number 28. POLIPHILVS, in turn, is mundane, yet flourishes in the perfection of the Vitruvian number 16.

Another obvious construction is the title of the work. In 'small' numbers (Fig. 9):

$$
\begin{aligned}
\text { HYPNEROTOMACHIA }= & 8+4+6+4+5+8+5+1+5+3+1+3+8 \\
& +9+1 \\
= & 71,
\end{aligned}
$$$$
\text { POLIPHILI }=6+5+2+9+6+8+9+2+9=56 .
$$

Alberti made frequent use of rational convergents to $\sqrt{3}$ in his architectural works. Tempio Malatesta, Rimini, provides one example-19:11, 26:15 (March 1999: pp. 259-269); others include Sant'Andrea, 26:15; Santa Maria Novella, 26:15; San Sebastiano, 12:7, 33:19. The ratio 71:41 is also a rational convergent to $\sqrt{ }$ 3:1 (March 1999: p. 66). This means that a line of length 112 divided into parts of lengths 71 and 41 is divided in the ratio $\sqrt{ } 3: 1$. This is a geometric mean cut. The half-length, 56, is an arithmetic mean cut. The numbers 71 and 56 are related in this way. Now, Poliphilo is infused with perfection since 56 is the double of the perfect number 28 (March 1999: pp. 20-21).

In De re aedificatoria, Alberti writes of powers and roots of numbers as providing harmonious relationships. He does not compute values for the unit cube,

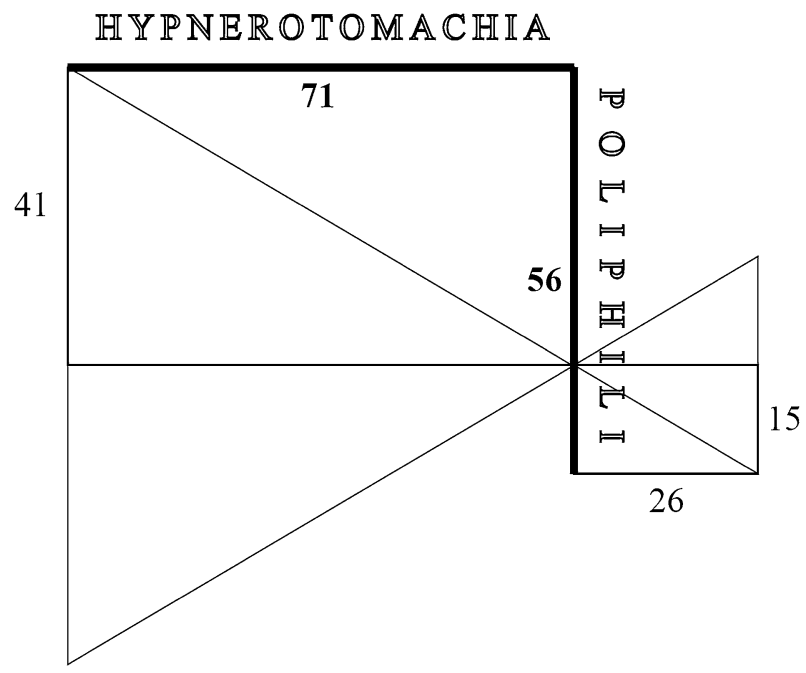

Fig. 9 Hypnerotomachia Poliphili enumerated as 71:56 
Fig. 10 Alberti's $2 \times 2 \times 2$ cube. He defines the length of a side as $\sqrt{ } 4$. By the Pythagorean theorem, the diameter of a face is then $\sqrt{ }(4+4)=\sqrt{ } 8$.

Similarly, the diameter of the cube is $\sqrt{ }(4+8)=\sqrt{ } 12$. This implies a proportional relationship of $\sqrt{ } 3: \sqrt{ } 2: \sqrt{ } 1$ between the diameter of a cube, the diameter of a face, and the length of its side

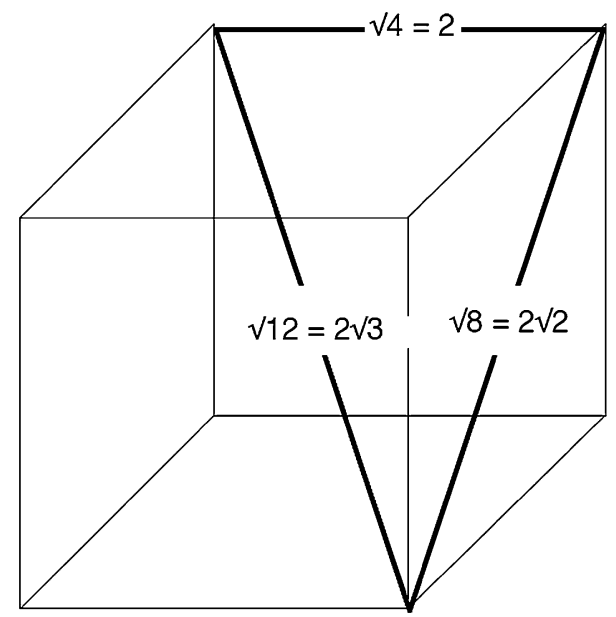

which would give him unit sides, unit surface area for the faces and unit volume, but on the $2 \times 2 \times 2$ cube (Fig. 10):

From it [the number 2] as root you produce an area of four, which if extended upward to a height equal to a side, will form a cube of eight. From this cube is derived the rule for outlines. First of all it provides the side of the cube, called the cube root, which generates an area of four and the full cube of eight. From this we derive that line running from one angle of the area to the opposite angle, the straight line dividing the square into two equal parts, for which reason it is called the diameter. The numerical value of this is not known, but it is obviously the square root of eight. Next there is the diameter of the cube, which we know for sure to be the square root of twelve (Alberti 1988: p. 307).

Alberti continues to describe the half equilateral triangle:

Lastly there is the line in the right-angled triangle whose two shorter sides are joined by a right angle, one being the square root of four, the other the square root of twelve. The third and longest line, which is subtended by the right angle is the square root of sixteen (Alberti 1988: p. 307).

The numerical value of a square root, such as $\sqrt{ } 2$ or $\sqrt{3}$, is not, as Alberti says, 'an actual number'. In modern terms, this is the distinction between rational numbers and the reals. By 'actual number' Alberti meant the rationals, which are represented today by all numbers of the form $p / q$ where $p$ and $q$ are integers. In Alberti's day, rational approximations had to be made to compute square and cube roots, except in those cases where the number itself was a square or a cube. Architectural evidence indicates that Alberti was familiar with several contemporary approximations for $\sqrt{ } 2, \sqrt{ } 3$ and $\sqrt{ } 5$. In particular, Alberti apparently knew several rational solutions to his half-equilateral triangle example (Figs. 11; 12).

The numbers 30 and 26 are familiar from earlier comments above, but now they are given a solid geometrical grounding in the dimensions of an equilateral triangle. 
Fig. 11 Alberti's halfequilateral triangle of base lengths $\sqrt{ } 4=2$ and altitude $2 \sqrt{3}$. The hypotenuse is $\sqrt{ }(4+12)=\sqrt{ } 16=4$

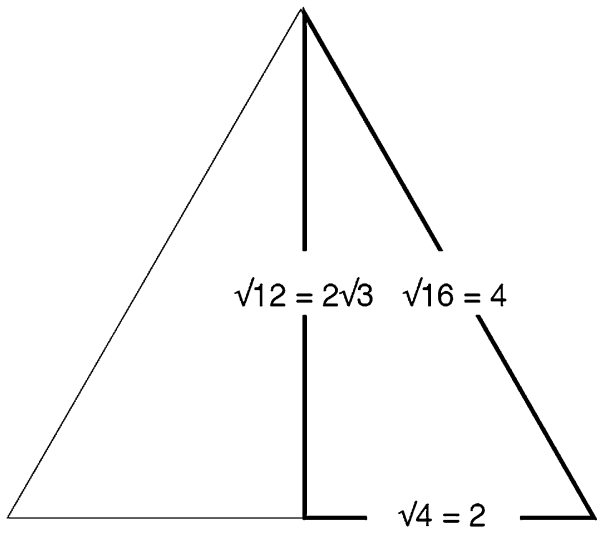

Fig. 12 Integer approximations to the sides of the halfequilateral triangle using the rational value $26 / 15$ for $\sqrt{ } 3$

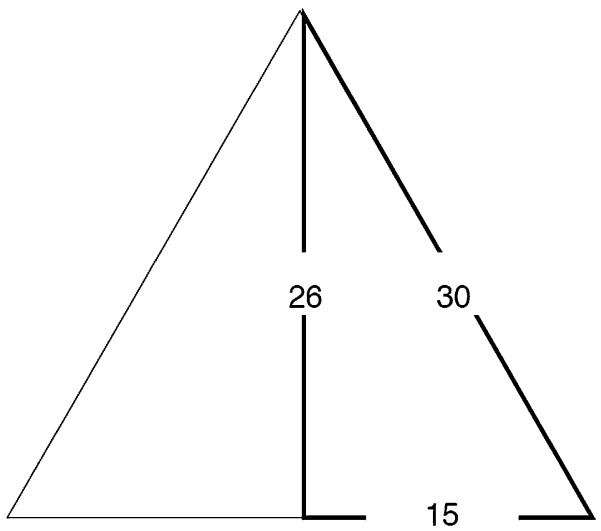

Yet it must be remembered that the equilateral triangle was frequently used after the twelfth century as nimbus, or halo, for the Almighty: more obviously it stood as a Christian symbol for the Trinity (Whittick 1971: pp. 272, 339). It is potent with such meanings.

The acrostic itself invites similar arithmogrammatic analysis. Once again the Divine numbers 26 and 36, found in Santa Maria Novella, appear prominently, bracketing the acrostic as a whole. But this count ignores the fact that the beginnings of the two books are marked with larger letters P and L. It is unlikely that this division is arbitrary. There are 24 chapters in the first book and 14 in the second. The ratio 24:14 is 12:7, a $\sqrt{ } 3$ division found in Alberti's architectural works. The second book starts with L, the initial for Alberti's adopted name LEO, while the first book starts with $\mathrm{P}$ whose numerical value, 60, corresponds to BAPTISTA ALBERTVS, 30 + 30 (Fig. 13):

An author writing in a highly inflected language like Latin has many opportunities to manipulate the construction and therefore the numbers. The acrostic had to be deliberately constructed, and it appears that that is so both for the 


\begin{tabular}{llllllllll}
$\mathrm{P}$ & 6 & $\mathrm{~F}$ & 6 & $\mathrm{~F}$ & 6 & $\mathrm{C}$ & 3 & $\mathrm{P}$ & 6 \\
$\mathrm{O}$ & 5 & $\mathrm{R}$ & 8 & $\mathrm{R}$ & 8 & $\mathrm{O}$ & 5 & $\mathrm{E}$ & 5 \\
$\mathrm{~L}$ & 2 & $\mathrm{~A}$ & 1 & $\mathrm{~A}$ & 1 & $\mathrm{~L}$ & 2 & $\mathrm{R}$ & 8 \\
$\mathrm{I}$ & 9 & $\mathrm{~T}$ & 1 & $\mathrm{~N}$ & 4 & $\mathrm{~V}$ & 2 & $\mathrm{~A}$ & 1 \\
$\mathrm{~A}$ & 1 & $\mathrm{E}$ & 5 & $\mathrm{C}$ & 3 & $\mathrm{M}$ & 3 & $\mathrm{M}$ & 3 \\
$\mathrm{M}$ & 3 & $\mathrm{R}$ & 8 & $\mathrm{I}$ & 9 & $\mathrm{~N}$ & 4 & $\mathrm{~A}$ & 1 \\
& & & & $\mathrm{~S}$ & 9 & $\mathrm{~A}$ & 1 & $\mathrm{~V}$ & 2 \\
& & & & $\mathrm{C}$ & 3 & & & $\mathrm{I}$ & 9 \\
& & & & $\mathrm{~V}$ & 2 & & & $\mathrm{~T}$ & 1 \\
& & & & $\mathrm{~S}$ & 9 & & & & \\
\hline & 26 & & & & & & & &
\end{tabular}

Fig. 13 Nine-chamber encoding of the acrostic derived from the leading letters to chapter headings
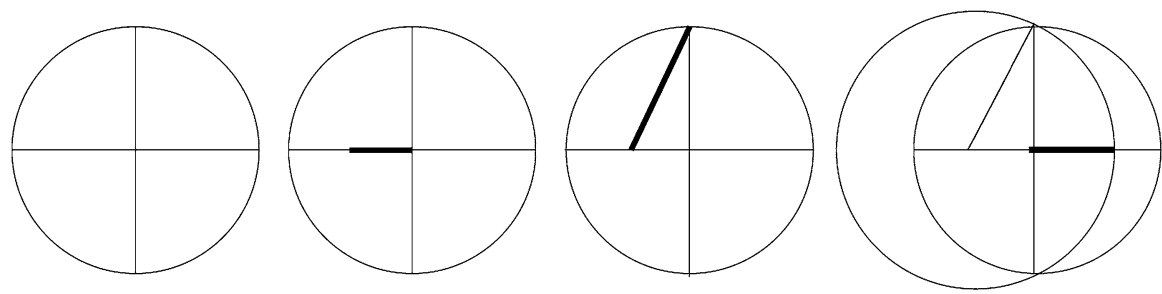

Fig. 14 Alberti's constructional sequence for a regular decagon

letters making the words and for the numerical values of the five words. The numbers 26 and 29 suggest a geometrical construction, since 29:13 is a rational convergent to $\sqrt{ } 5$, the diagonal of the $2 \times 1$ double square. It is this diagonal which is struck in Alberti's construction for the regular decagon (Fig. 14):

We may also use a circle to define a decagon: we draw a circle with two diameters intersecting one another at right angles, and divide any one of the semidiameters into two equal parts. From this point of division we take a straight line slanting up to the top of the other diameter. If you then subtract from this line one quarter of the diameter, the distance remaining will equal the length of one side of the decagon (Alberti 1988: p. 196).

A circle of radius 26 is drawn with two orthogonal diameters. The center point of a radius is at a distance 13 . The semi-radius and a perpendicular radius make two sides of a $26 \times 13$ double square. The rational diagonal of this double square is 29 using the value 29:13 for $\sqrt{ } 5$. "Subtract from this line one quarter of the diameter" gives $29-13=16$. "The distance remaining" is 16 , the length of the side of the decagon inscribed within a circle of radius 26 . The ratio $29: 26, \sqrt{ } 5: \sqrt{ } 4$, is convergent to the diagonal of the double square to its long side, the radius (Fig. 15).

This same geometric construction also provides the length of sides for the regular pentagon and the heptagon. Compare this description in Hypnerotomachia of the geometrical construction for the seven-sided Fountain of Venus. 

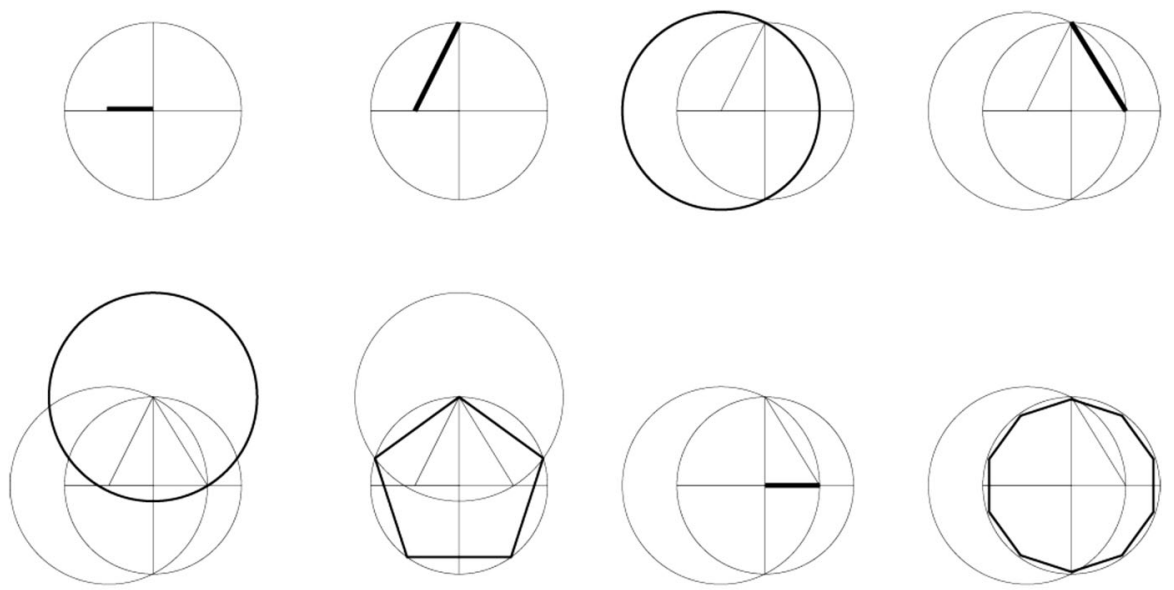

5
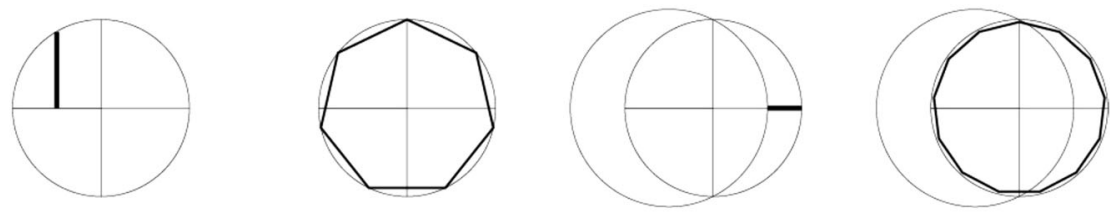

7

13

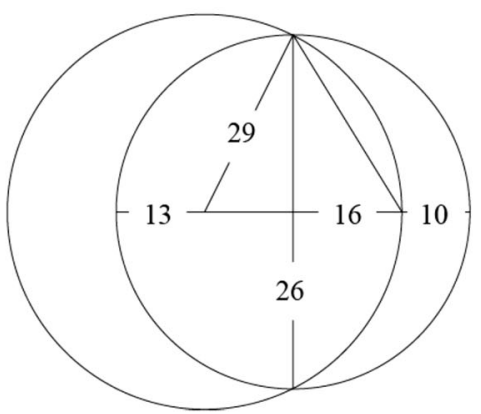

Fig. 15 The exact geometric construction for the regular pentagon and decagon showing integer values when the rational ratio 29:13 is used for $\sqrt{ } 5: 1$. Traditional approximate values for the sides of the regular heptagon and 13-gon are also illustrated. The latter would have been required for the 26-sided roundels in Santa Maria Novella

Having drawn a circle, construct an equilateral triangle on its radius, then draw a line through the middle of the side adjacent to the circumference, and that length gives the sevenfold division of the circular figure (Godwin 1999: p. 359). 
Hypnerotomachia Poliphili contains descriptions of antique buildings which the hero, Poliphilo (lover of multiplicity), comes across in a strife-ridden dream pursuing his love, Polia (multiplicity). These descriptions are measured parsimoniously, requiring the reader to compute the complete set of measurements according to the practices of the day. Ian White has done this in several reconstructions. He makes use of the rational numbers used by practitioners at that time to express the values of irrational square roots (decimals had not yet been introduced). The more common of these are set out in (March 1999), where the methods of computation for general cases are given. In particular, White cites 17:12 for $\sqrt{ } 2: 1$ in his rendering of the Great Gate, and 38:17 for $\sqrt{ } 5: 1$ in reconstructing the decagonal Temple of Venus Physizoa (White 2004; Ian White 2015).

Early on in his adventures, accompanied by Logistica, Poliphilo confronts a 'mysterious thing', mysteriosaméte, an obelisk set in the centre of a circle of one hundred arches (Fig. 16). At the base of the structure is a translucent cube, one and a half passi (paces) high. A ruby-red cylinder whose diameter is the width of the cube, di diametro passo uno \& semi, surmounts it and is two feet high, dui pedi alta.

Inscribed in the top circular face is an equilateral triangle from which an opaque black prism rises another one and half paces, di altitudine passo uno \& semi. On each rectangular face of the prism there is statue standing on the uncovered portion of the cylindrical top. The hands of these three figures meet at the corners of the prism where each holds a cornucopia. The vertical edges of the prism are, in part, cut back one foot two inches, uno pede \& sextante, to make room for the cornucopia. Above this, a golden triangular pyramid is carried by three recumbent sphinx-like beasts, one wild faced, one half animal-half human, and one humanoid. The pyramid is five times the height of its prismatic plinth.

To proceed, it is convenient to convert the different Roman measures to unciae, or inches. 1 pes (foot) is 12 unciae (inches), 21/2 pedes make 1 gradus, or 30 inches, 2 gradii make 1 passus, 5 pedes or 60 inches. The base is thus a 90 inch cube, the cylinder is 90 inches in diameter and 24 inches high, and the triangular prism is 90 inches high. It was well known that the square on the side of an inscribed equilateral triangle in a circle was three times the square on the radius; that is, diameter:side :: $\sqrt{ } 4: \sqrt{ } 3$. A rational value, in use at the time, for $\sqrt{ } 4: \sqrt{ } 3$ was $15: 13$. This would make the width of the prism 78 inches $(6 \times 15=90$ inches, the diameter of the circle; $6 \times 13=78$ inches, the side of the inscribed equilateral triangle).

The height of the pyramid is five times the side of this triangle, $5 \times 78=390$ inches. From the ground, the height of the cube is 90 inches, to the top of the cylinder is $90+24=114$ inches, to the top of triangular prism is $114+90=204$ inches, and to the apex of the pyramid is $204+390=594$ inches. Prior to seeing the obelisk, Logistica told Poliphilo: 'I want you to know that things perceived give more enjoyment to the intellect than to the senses alone'. Then, contemplating the obelisk itself, Logistica declares: 'The celestial harmony is in these figures'. Three Greek words are inscribed on the cylinder; in Godwin's translation (1999) they are 'unspeakable, inseparable, inscrutable'. On the four faces of the cube is another Greek inscription meaning 'hard to comprehend'. It is extremely unlikely that these numbers are arbitrary; they are almost certainly of occult, hidden significance. 
$594=27 \times 22$

$27: 22=\sqrt{ } 3: \sqrt{ } 2$

$204=17 \times 12$

$17: 12=\sqrt{ } 2: 1$

$19: 6=\sqrt{ } 10=\pi: 1$

$10: 9=\sqrt{5}: \sqrt{ } 4$

90
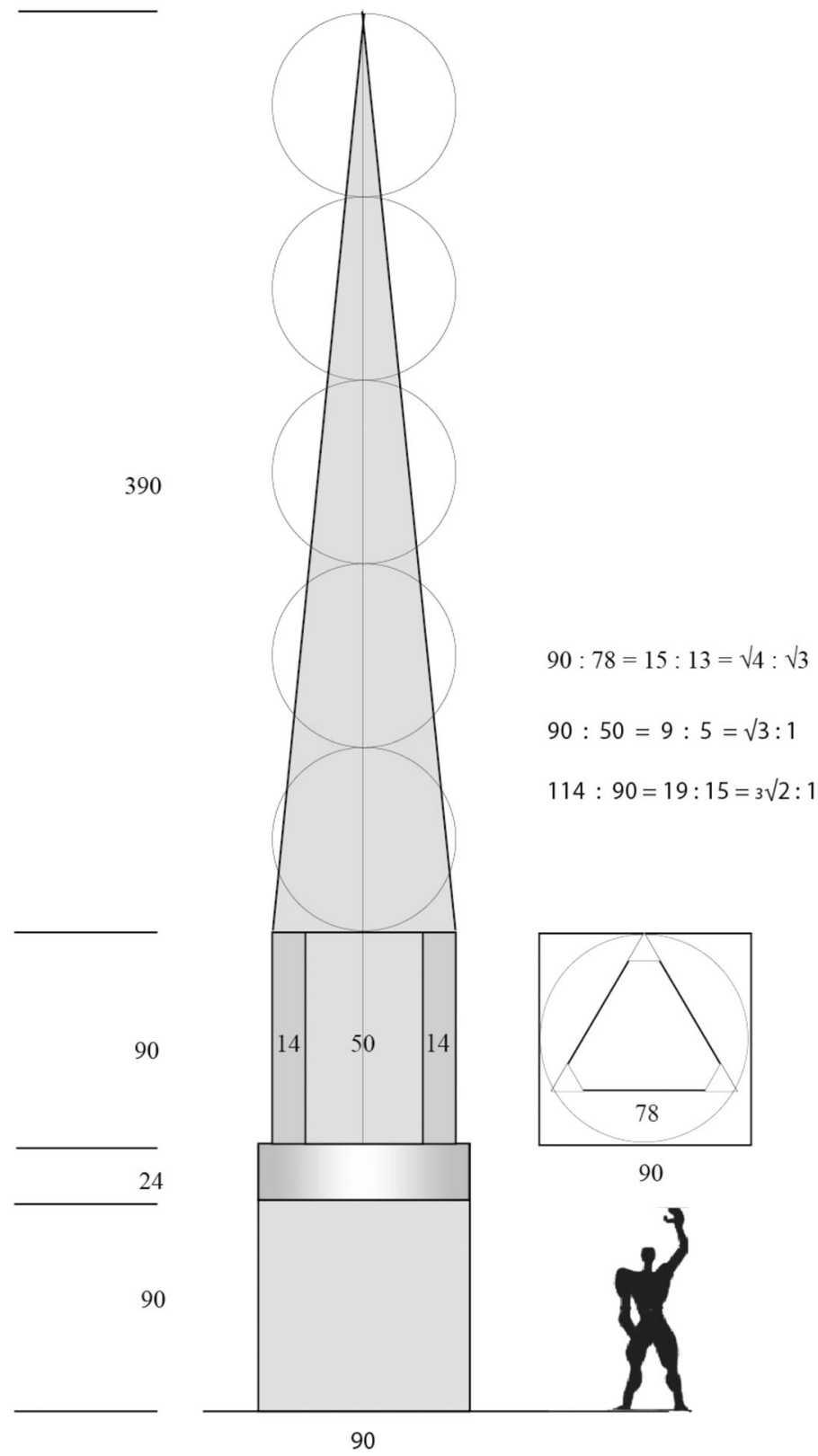

Fig. 16 Reconstructed elevation and plan of the obelisk in Hypnerotomachia Poliphili

The current arithmetic, at the time, was Nicomachean. Numbers were often conceived as shapes. A number such as 9 is a $3 \times 3$ square, the same as today. A number such as 12 is a $4 \times 3$ oblong. There were solid numbers too, 8 is a 
$2 \times 2 \times 2$ cube, 12 is a $2 \times 2 \times 3$ 'beam', 18 is a $2 \times 3 \times 3$ 'brick', and $2 \times 3 \times 5=30$ is said to be 'scalene'. In modern terms, the numbers are factored, or partially so.

From the dimensions of the obelisk: 90 is an oblong $10 \times 9,114$ is an oblong $19 \times 6,204$ is an oblong $17 \times 12,390$ is an oblong $26 \times 15$, and 594 is an oblong $27 \times 22$, choosing in each case the rectangle that is closest to a square. A clear pattern emerges which would have been familiar to an individual well versed in the arithmetic of the day. For example, a $17 \times 12$ room has an area of 204 and is in proportion $\sqrt{ } 2: 1$. While the area of a $26 \times 15$ room is 390 in proportion to $\sqrt{ } 3: 1$; the area of a $10 \times 9$ room is 90 in proportion $\sqrt{ } 5: \sqrt{ } 4$; the area of a room $27 \times 22$ is 594 in the proportion $\sqrt{ } 3: \sqrt{ } 2$. Direct proportional relations are to be found in the faces of the triangular prism: $90 \times 78$ inches, a proportion of $15: 13$, or $\sqrt{ } 4: \sqrt{ } 3$, the ratio which echoes the determination of the width of the prism. So far, $\sqrt{ } 2, \sqrt{ } 3, \sqrt{ } 4$, and $\sqrt{ } 5$ are all represented by this kind of numerical decomposition (Fig. 17).

The obelisk embodies those innate correspondentiae, powers and roots of numbers, spoken of with enthusiasm by Leon Battista Alberti in De re aedificatoria. Yet more, the pyramid has inscribed upon its faces a circle apiece. Only one circle may be seen full on at a time, as Logistica is at pains to point out. Each circle is accompanied by an Attic Greek letter: N, nu; O, omicron; and $\Omega$, omega. These letters carried numerical values in ancient Greek since no separate symbols for the numerals existed. Their 'root' values, pythmen, are 5, 7 and 8. Thus, hidden behind each circle is a number pair $(8,7),(8,5)$ and $(7,5)$ (Fig. 18).

It is surely no accident that these are basic numbers associated with the "celestial harmony' of the primary Platonic elements: the equilateral triangle, the regular pentagon and square and which make up the three world-making polygonal faces of the tetrahedron, octahedron, icosahedron, dodecahedron and cube.

The number 114 factors into $19 \times 6$, which is in proportion to $\sqrt{ } 10: 1$, the diagonal of a $3 \times 1$ rectangle, but is also an early value for $\pi$. In fact, a contemporary computational, converging sequence for $\sqrt{ } 10: 1$ would have been $3: 1$ (a Biblical under estimate), 10:3 (over estimate), 13:4 (over), 16:5 (over), 19:6 (over), 22:7 (under). The affinity of $\sqrt{ } 10$ to $\pi$ is apparent given the traditional

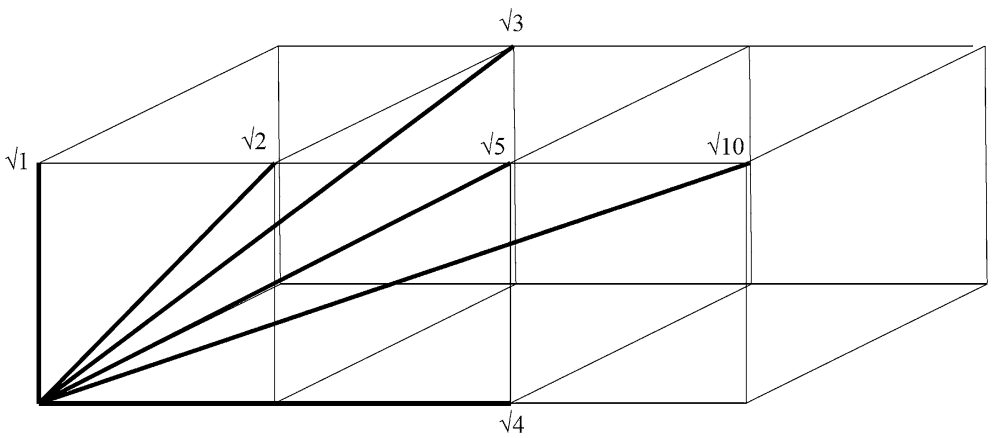

Fig. 17 Square roots hidden in the obelisk $\sqrt{ } 1, \sqrt{ } 2, \sqrt{ } 3, \sqrt{ } 4 . \sqrt{ } 5 . \sqrt{ } 10$ associated with the unit cube and the triple cube 


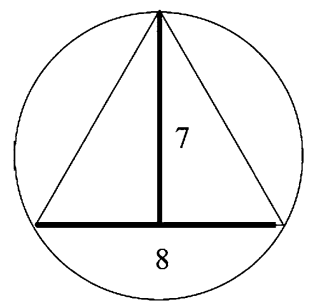

$8: 7=\sqrt{ } 4: \sqrt{3}$

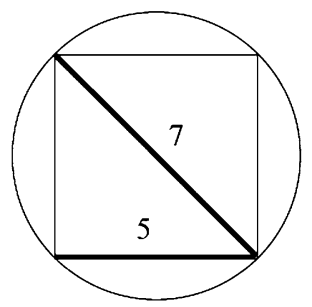

$7: 5=\sqrt{ } 2: 1$

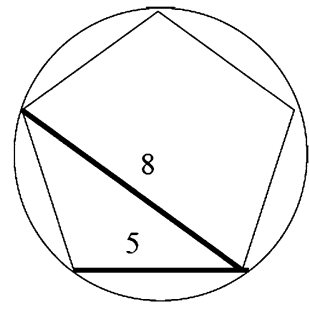

$8: 5=(\sqrt{ } 5-1): 2$

Fig. 18 The numbers 5, 7, 8 associated with the primary Platonic elements
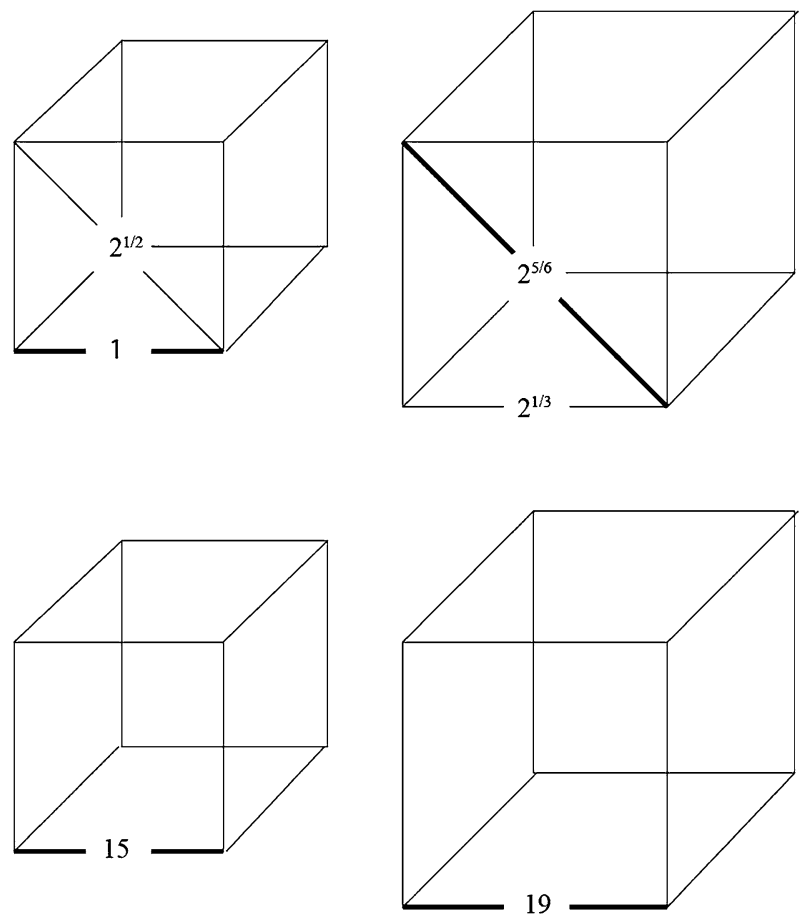

Fig. 19 The Delic problem of doubling the volume of a cube employing the rational value of 19:15 for $3 \sqrt{ } 2: 1$

practical value of $22: 7$ for $\pi: 1$. That this allusion occurs with the cylinder is surely appropriate.

Even more arcane is the ratio of the height of the cube and cylinder to the diameter of the cylinder, 114:90 :: 19:15, a good rational value for $\sqrt[3]{2}: 1$. This is a solution to the Delic problem of doubling the volume of a cube (Fig. 19).

The seemingly trivial information that the vertical edges of the triangular prism are cut back by 14 inches also has an unexpected relation to the Platonic scheme. 

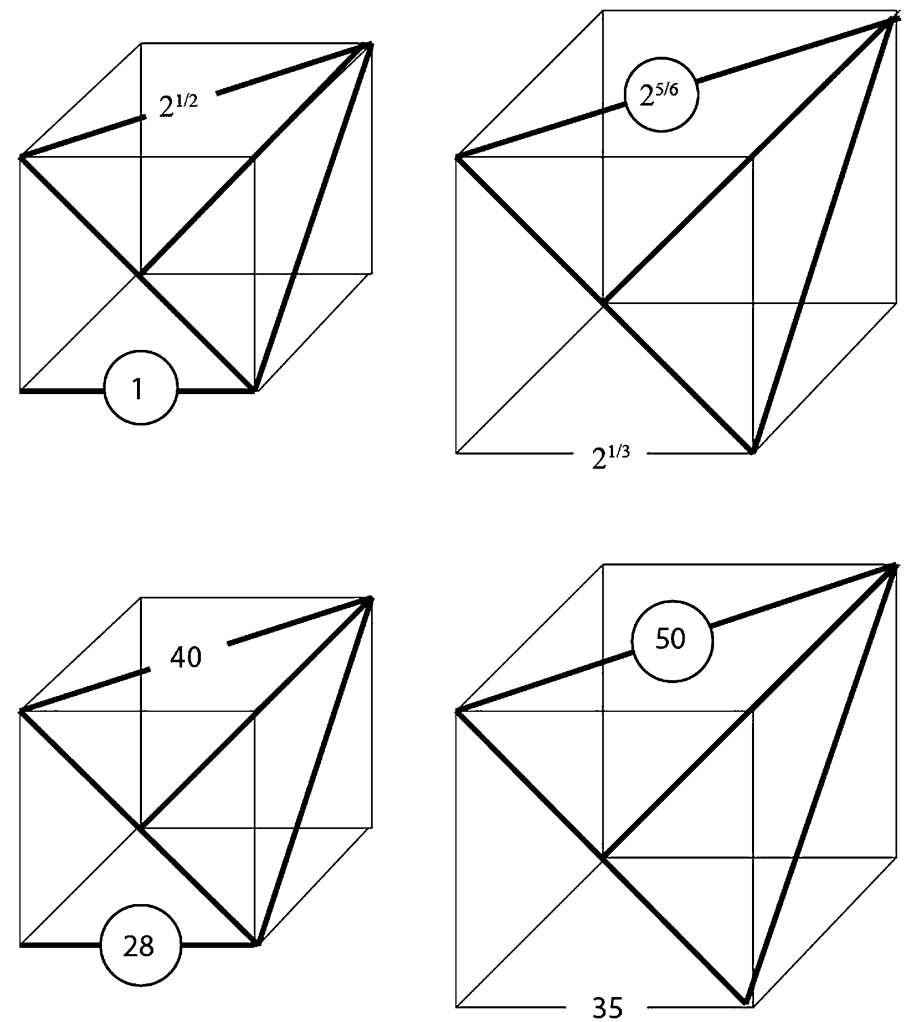

Fig. 20 The ratio 50:28 shown as the doubling of the tetrahedron inscribed in a cube

The face of the prism is essentially divided into a flat face 50 inches wide and two 14 inch chamfers, together subtracting 28 inches from the full width, 78 inches. The ratio 50:28 is curious (Fig. 20).

It is also the ratio of the side of a cube, 28, circumscribing a tetrahedron (and therefore both figures circumscribed by a common sphere) to the side of a tetrahedron of twice the volume, 50 .

Arithmetically, this computation employs the ratio $5: 4$ for $\sqrt[3]{2}$ : and 10:7 for $\sqrt{ } 2: 1$. If the side of the cube is 28 , then the side of the circumscribed tetrahedron (the diagonal of the face of the cube) is $40,28 \times 10 / 7$. The cube of twice the volume has a side of length $35,28 \times 5 / 4$, and the diagonal of the face, that is the side of the tetrahedron of twice the volume, is $50,35 \times 10 / 7$. This computation is essentially Euclidean in the arithmeticized form which Piero della Francesca, for example, exercised at the time (Field 1997; Davis 1977) (Fig. 21).

The ratio of the height of the obelisk to its base is 594:90 :: 33:5. This again is surely no accident. The rectangle circumscribing an equilateral triangle is $\sqrt{ } 4: \sqrt{ } 3$. A rational value for this is $38: 33$ derived from $\sqrt{ } 3=33: 19, \sqrt{ } 4=2: 1$. A square subtracted from this rectangle leaves a rectangle of 33:5, the rectangular space occupied by the obelisk. It may not be a coincidence that the number of chapters in 
Fig. 21 The obelisk contained within the $33 \times 5$ rectangle obtained by subtracting a square from the circumscribing rectangle of an equilateral triangle using the rational value $38: 33$ for $\sqrt{ } 4: \sqrt{ } 3$

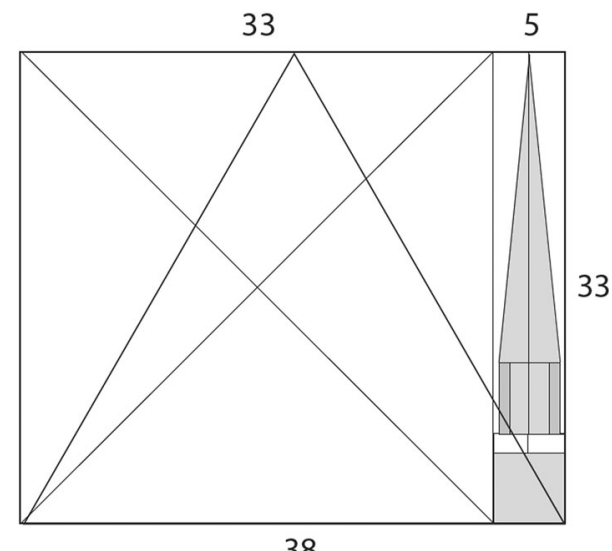

38

the book is 38 while the number of Alberti's adopted Latin name, LEO, in Nichomachean triangular numbers is $\Delta 2+\Delta 5+\Delta 5=3+15+15=33$ (March1998: pp. 22-30; Scholem 1974: pp. 337-343). The ratio 33:5 is the Euclidean 'separation' of 38:33 (Euclid, V.Def. 15; March 1998: p. 10). Alberti was known to have read Euclid.

In Book 2 of Hypnerotomachia Poliphili, the author describes the geometry of the circular Cytherean Island. He uses the Biblical ratio for the circumference of the circle, namely three times the diameter. The diameter is 1000 passi. This was divided into thirds. Each third would be exactly 333 passi and 2 pedes $(6$ pedes $=1$ passus), but the author feigns not to know precisely and writes that a third is ' 333 paces, one foot, two palms and a little more'. It is as if the author is encouraging the reader to ignore anything less than a passus. This is confirmed on the drawing where one-third, uno tertio, is shown as .CCC.XXXIII, or as an arithmogram.

$3+3+3+300+300+300+9+9+9=936$, using the full numbers in the nine-square table. This arithmogram enumerates Alberti's name.

Below the final chapter introduced by the letter $\mathrm{T}$, the date of the book is given as .M.CCCC.LXVII. Kalendis Maii, including the punctuation parsing the date with periods at unusual places. Given the extraordinarily occult computations in the text, it is most unlikely that this date is an accident, even more so that it represents the actual date of the manuscript's completion. Dedicated as it was to the Floralia, the festival of Flora, the Kalends of May seems an appropriate date to associate with this bucolic, pagan tale. For the year, the author could have used the alternate Roman form MDMLXVII, but in at least three contemporaneous architectural instances Alberti chooses not to use this abbreviated form. At the Tempio Malatestiano, the year 1450 is inscribed as.M.CCCC.L.; at the Rucellai sepulchre, the year 1467 is inscribed MCCCCLXVII without punctuation; and at Santa Maria Novella, the year 1470 is inscribed MCCCCLXX, again without punctuation. M has already been identified with both ALBERTVS and BAPTISTA through the number 30 they share in common..CCCC. reads $3+3+3+3=12$, or LEO. The digits of the year 1467 sum to $1+4+6+7=18=9+3+6$, Alberti's encoded name. 
Moreover, a Renaissance Romanist might ask what year 1467 was ab urbe condita, since the founding of Rome. Using Varro's dating, 753 BCE, the year would be $1467+753=2220$ AUD, or in Roman numerals MMCCXX. As an arithmogram this elegant number counts as $30+30+3+3+300+300=666$. Could the author have intended this? It is well known that 666 uses once each, all the Roman letter- numbers through $\mathrm{D}=500, \mathrm{C}=100, \mathrm{~L}=50, \mathrm{X}=10, \mathrm{~V}=5$ and $\mathrm{I}=1$, DCLXVI. Note that, on the island, the one-sixth measure, 166 paces, CLXVI, is all of these but D. This suggests that 666 is not unexpected. It is the sum of all 36 terms in the $6 \times 6$ magic square for the Sun, LEO. Again, $6+6+6=18=9+3+6$, or Alberti's full name.

On the page following the final chapter is an epitaph to Polia (Fig. 22).

The consideration with which a written epitaph is constructed must surely echo the design of an architectural monument. The inscription EPITAPHIVMPOLIAE is made from words of 10 and 6 letters, making 16 in all. Here is Vitruvian perfection: 6 and 10 are 'perfect' numbers and combined they make the 'most perfect' 16, perfectissimum decusis sexis (Vitruvius, II.1). St. Augustine relates the numbers 6 and 10 to the dimensions of Noah's Ark and by analogy interprets them as symbols of Christ and the Church (St Augustine, City of God, XV.26). Alberti writes: 'The sixfold is one of the very few [numbers] which is called 'perfect', because it is the sum of its integral divisors' (Alberti 1988: p. 304); this is the mathematical requirement for all mathematical perfect numbers such as $1+2+4+7$ $+14=28$.

Of 10, he writes: 'Aristotle thought the tenth the most perfect number of all; perhaps, as some interpret, because its square equals the cubes of four consecutive numbers' (Alberti 1988: 304). That is, the equation $10^{2}=1^{3}+2^{3}+3^{3}+4^{3}$.

Alberti generates the proportions of the five orders from the Vitruvian perfect numbers 6 and 10. The extreme columns are either fat in which the height of the column is 6 times the diameter, or thin in which this ratio is 10:1. The Ionic is the arithmetic mean $(10+6) / 2$, or $8: 1$. The remaining two derive from the means $(8+10) / 2=9$, the Corinthian, and $(8+6) / 2=7$, the Doric (Alberti 1988: p. 309). Tavernor has written about the use of the numbers 6 and 10 in Alberti's architectural practice, but also concerning his observations on the dimensions of the human body in De Statua (Tavernor 1998: p. 30-43). The occurrence of this signature ratio in the inscription is itself telling, but the arithmogrammatic evidence is also revealing.

$$
\text { EPITAPHIVM }=5+6+9+1+1+6+8+9+2+3=50
$$

Fig. 22 The epitaph to Polia that appears following the final chapter
EPITAPHIVMPOLIAE

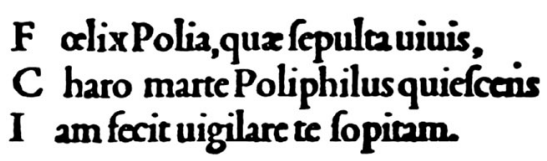




$$
\text { POLIAE }=6+5+2+9+1+5=28
$$

The ratio 50:28 at first glance may seem of no consequence. Consider that the ratio is compound. In contemporary usage this might appear as

$$
\begin{gathered}
5: 4 \\
|\quad| \\
10: 7 \\
\hline 50: 28
\end{gathered}
$$

where the lines indicate multiplication, but the procedure is referred to as the 'addition' of ratios by Nicole Oresme at the time (Grant 1966: pp. 312-317). The 'addition' is equivalent to

$$
\begin{aligned}
& 2^{1 / 3}: 1 \\
& 2^{1 / 2}: 1 \\
& 2^{5 / 6}: 1
\end{aligned}
$$

While this may appear modern, fractional exponents were pioneered by Bishop Oresme of Lisieux in the fourteenth century, but not with the modern notation used here. The equivalence is derived from the very common rational approximation for $\sqrt{ } 2$ as $10 / 7$ and an equally common rational value for $\sqrt[3]{2}$ as 5/4.

According to Vitruvius (II.3.3), the Greeks used two types of brick: the tetradoron and the pentadoron. The first is a $4 \times 4 \times 4$ cube, and the second a $5 \times 5 \times 5$ cube measured by the doron, a palm. Alberti makes reference to these bricks which 'the ancients used' (Alberti 1988: p. 52). The volume of the first brick to the volume of the second is in the ratio 64:125. The second brick, for all practical purposes, has twice the volume of the first, $2 \times 64=128$ - "within a certain inexpressible fraction, which is easy to make but hard to say", as Leonardo da Vinci was to record early in the sixteenth century (Marioni 1974: p. 73).

The combined ratio $2^{5 / 6}: 1$ is simply the ratio of the diagonal of the face of the doubled cube to the side of the primary, unit cube (March 1999: p. 264, Table 5). These are precisely typical of ratios that Alberti describes as innatae correspondentiae. While the rational approximation 5/4 is not as good as the value 29/23 which was cited above (Fig. 13) it is nevertheless a representative of the class of rational numbers,

$5 / 4,9 / 7,14 / 11,19 / 15,24 / 19,29 / 23, \ldots$, which stand proxy for $\sqrt[3]{2}$ in ever closer approximations (Fowler 1987:120). In an attempt to reconcile the multitudes of 
arithmetic with the magnitudes of geometry, the 50:28 ratio evokes profound classical concerns.

This arithmogrammatic equation is appropriate for the epitaph. But by whom is it written? There is a second acrostic which has been overlooked by commentators. The letters F C I are ostentatiously separated from the text of the epitaph. Read in reverse order and evaluated by their 'small' nine chambers numbers, the acrostic reads 936 , mirabile dictu, the very digits of Alberti's full arithmogram, 936.

This extraordinary dreamwork is thus bracketed between two encoded expressions of Alberti's name-the solitary M for ALBERTVS sharing the number 30, which also doubles for BAPTISTA, and LEO BAPTISTA ALBERTVS which sums to the number 936, signaled by the letters I C F. Further, the principal, well-known acrostic gives emphasis to the enlarged letters $\mathrm{P}$ and $\mathrm{L}$ at the beginning of each of the two books. BAPTISTA ALBERTVS, $30+30=60$, and P share the number 60, while $\mathrm{L}$ is the initial of Alberti's adopted Latin name, LEO. The 'small' number equivalent of his full name is 72 , another divine number, but only because Alberti added the name LEO to his birth name in the early 1450 s.

In addition, the first word and last word of the acrostic sum to 26 and 36 respectively. How much of an accident is it that these two divinely invested numbers multiply to announce, once more, LEO BAPTISTA ALBERTVS, $26 \times 36=936$, the very same digits revealed in the previously neglected reverse acrostic of the epitaph?

Having made the assumption that Alberti was the author of Hypnerotomachia, evidence of an arithmogrammatical kind has been assembled to unmask the perpetrator of this subversive novel. This theory, in the legal sense, was required initially in order to suggest the kind of coded evidence that might exist in the text. Alberti's acknowledged skills in cryptography and geometry, and the proportional signatures of his architectural modus operandi, have provided signposts for the several byways of this investigation.

\section{Postscript}

This investigation started in 1996 over dinner at MIT after I had delivered a lecture to the School of Architecture and Urban Planning on some themes later published in Architectonics of Humanism (March 1996). Liane Lefaivre was present and we briefly discussed her book on Hypnerotomachia Poliphili, then about to go to press with MIT, and her determined claim that Alberti was the novel's author. I do not recall Mark Jarzombek's position in this regard, also present at the dinner, although his own book, On Leon Baptista Alberti: His Literary and Aesthetic Theories (1989) makes no mention of Hypnerotomachia Poliphili.

My own investigation was both delayed yet encouraged by my preparations of Architectonics for publication. On and off since 1999, I have returned to a limited enquiry into the possibility of finding cryptographic evidence of Alberti's authorship in the text, especially since I had revealed-at least to my own satisfaction-his use of letter-number encryptions in his architectural works. 
Scrap notes piled up to no purpose. Then I received an invitation from Kim Williams to open the Nexus IV conference on mathematics and architecture in Óbidos, Portugal, 2002. There Kim presented me with a copy of her recently published paper 'Plagiary in the Renaissance' (Williams 2002), on the relationship of Piero della Francesca's mathematical works to those of Luca Pacioli. Then, during the course of the conference, Alberto Pérez-Gómez presented a paper (2015) which included references to the painting of Pacioli and to the novel, Hypnerotomachia. He repeated several points upon which I differed, or had further comments.

I also had conversations, at Óbidos, with Mário Júlio Teixeira Krüger, who had just started work on the first Portuguese translation of De re aedificatoria. He had taken me to the Sala dos Capelos at Coimbra University where he pointed out the grotesco painted ceiling. It is his belief that the motifs depicted in the ceiling were derived from Hypnerotomachia, a copy of which was held at the monastery of St. Clara in Coimbra, at the time the painting was executed. "I am also on the side of Alberti's Poliphili," he later wrote me. Also around this time I had a conversation with Ian White concerning the use of rational values for roots in the proportional design of Renaissance architecture.

I also thank the UCLA Center for Medieval and Renaissance Studies for their generous support over the years.

\section{References}

Alberti, Leon Battista. 1987. Dinner Pieces, David Marsh, trans. Binghamton NY: ACMRS Publications. Alberti, Leon Battista. 1988. On the Art of Building in Ten Books, Joseph Rykwert, Neil Leach, Robert Tavernor, trans. Cambridge MA: MIT Press.

Barolini, Helen. 1992. Aldus and His Dream Book. New York: Italica Press.

Borsi, Franco. 1975 Leon Battista Alberti. Oxford: Phaidon.

Davis, Margaret Daly. 1977. Piero della Francesca's Mathematical Treatises. Ravenna: Longo Editore. Bonaventure (Saint). 1963. The Breviloquium, José De Vinck, trans. Vol. II in The Works of Bonaventure. Paterson NJ: St. Anthony Guild Press.

Field, Judith V. 1997. The Invention of Infinity: Mathematics and Art in the Renaissance. Oxford: Oxford University Press.

Fowler, David H. 1987. The Mathematics of Plato's Academy: a Reconstruction. Oxford: Clarendon Press.

Godwin, Jocelyn, trans. 1999. Francesco Colonna. Hypnerotomachia Poliphili (Cambridge MA: The MIT Press).

Grant, Edward, ed. 1966. Nicole Oresme. De proportionibus proportionum and Ad pauca respicientes. Madison, Milwaukee, and London: The University of Wisconsin Press.

Heath, Thomas. 1981. A History of Greek Mathematics, vol. 1. New York: Dover Publications.

Jarzombek, Mark. 1989. On Leon Baptista Alberti: His Literary and Aesthetic Theories. Cambridge: MIT Press, 1989.

Kahn, David. 1996. The Codebreakers: The Story of Secret Writing. New York: Scribner.

Lefaivre, Liane. 1997. Leon Battista Alberti's Hypnerotomachia Poliphili. Cambridge MA: MIT Press.

March, Lionel. 1996. 'Renaissance mathematics and architectural proportion in Alberti's De re aedificatoria' Architectural Research Quarterly 2.1 (Cambridge: Cambridge University Press).

March, Lionel. 1998. Architectonics of Humanism: Essays on Number in Architecture. London: Academy Editions. 
March, Lionel. 1999. Proportional Design in L. B. Alberti's Tempio Malatesta. Architectural Research Quarterly 3(3): 259-269.

Marioni, Augusto. 1974. The Writer: Leonardo's Literary Legacy. In: The Unknown Leonardo, Ladislao Reti, ed., pp. 56-85. New York: McGraw-Hill.

Pérez-Gómez, Alberto. 1993. Polyphilo or the Dark Forest Revisited. Cambridge: MIT Press.

Pérez-Gómez, Alberto. 2015. Architecture as Verb and the Ethics of Making. In: Architecture and Mathematics from Antiquity to the Future, Kim Williams and Michael Ostwald, eds., vol. II, pp. 661-673. Cham: Springer.

Rowland, Ingrid D. 1998. The Culture of the High Renaissance. Cambridge: Cambridge University Press. Scholem, G. 1974. Kabbalah. Jerusalem: Keter Publishing House.

Strauss, Leo. 1988. Persecution and the Art of Writing. Chicago: The University of Chicago Press. Tavernor, Robert. 1998. On Albert and the Art of Building. New Haven: Yale University Press.

Whittick, Arnold. 1971. Symbols: Signs and their Meaning and Uses in Design. London: Leonardo Hill. Williams, Kim. 2002. Plagiary in the Renaissance. The Mathematical Intelligencer 24, 2: 45-57.

Williams, Kim, March, Lionel, Wassell, Stephen R. 2010. The Mathematical Works of Leon Battista Alberti. Basel: Birkhäuser.

White, Ian. 2004. Essay on Architecture. In: Hypnerotomachia Poliphili, CD. Oakland CA: Octavo Edition.

White, Ian. 2015. Mathematical design in Poliphilo's imaginary building, the Temple of Venus. Word and Image 31 (2) Special Issue: Hypnerotomachia Poliphili Revisited: 164-191.

Lionel March holds a BA (Hons) in Mathematics and Architecture, Diploma in Architecture, MA, and Doctor of Science (ScD) from the University of Cambridge. He has held fellowships with the Royal Society of Arts, the Institute of Mathematics and its Applications, and the Royal College of Art. He was founding director of the Centre for Land Use and Built Form Studies, now the Martin Centre for Architectural and Urban Studies, University of Cambridge. He has held Professorships in Engineering (Waterloo, Ontario), Technology (The Open University), Architecture and Urban Design, and Design and Computation (University of California, Los Angeles). He was Rector and Vice-Provost (Royal College of Art, London). He was co-editor with Sir Leslie Martin of the twelve volume Cambridge Architectural and Urban Studies, Cambridge University Press. He was founding editor in 1967 of the bi-monthly refereed journal Environment and Planning B, now Planning and Design. Relevant recent publications include Architectonics of Humanism: Essay on Number in Architecture (1999); 'Renaissance mathematics and architectural proportion in Alberti's De Re Aedificatoria', Architectural Research Quarterly (ARQ), 2/1, 1996, 54-65; 'Proportional design in L.B. Alberti's Tempio Malatestiano, Rimini', ARQ, 3/3, 1999, 259-269; 'Palladio, Pythagoreanism and Renaissance Mathematics', Nexus Network Journal, 10/2, 2008, 227-243. Lionel March is currently Visiting Scholar, Martin Centre for Architectural and Urban Studies, Department of Architecture, University of Cambridge, and emeritus member, Center for Medieval and Renaissance Studies, University of California, Los Angeles 